\title{
FAKTOR-FAKTOR YANG MEMPENGARUHI KUALITAS KONSTRUKSI RUMAH MENENGAH DAN MEWAH DI SURABAYA
}

\author{
Ambrosius Mintardjo ${ }^{1}$, Timoticin Kwanda ${ }^{2}$ and Jani Rahardjo ${ }^{3}$ \\ Program Studi Magister Teknik Sipil \\ 1m01516010@john.petra.ac.id, ${ }^{2}$ cornelia@petra.ac.id, 3jani@petra.ac.id
}

\begin{abstract}
ABSTRAK: Faktor kualitas menjadi hal yang dipertimbangkan masyarakat dalam membeli rumah. Masyarakat mau membayar lebih untuk memperoleh rumah berkualitas baik, karena hal itu akan meningkatkan nilai jual. Oleh karena itu, sangat penting untuk mengetahui faktorfaktor yang mempengaruhi kualitas konstruksi rumah di Surabaya. Dalam penelitian ini responden diminta untuk mengisi pertanyaan tentang kualitas konstruksi rumah di Surabaya dan pengaruh faktor-faktor yang mempengaruhinya. Hasil dari penelitian ini ditemukan delapan faktor yang dipertimbangkan dalam penentuan kualitas konstruksi rumah menengah dan mewah di Surabaya yaitu pengalokasian dana untuk manajemen kualitas dalam budget proyek, peninjauan secara menyeluruh terhadap desain arsitektur dan struktur, manajemen supplier, manajemen proses, manajemen sumber daya manusia, standardisasi tertulis dalam kontrak, orientasi terhadap kepuasan pelanggan, dan spesifikasi konstruksi dan gambar yang jelas. Dari kedelapan faktor tersebut, faktor yang sangat berpengaruh ialah faktor speksifikasi konstruksi dan gambar yang jelas.
\end{abstract}

Kata kunci: kualitas konstruksi, rumah menengah dan mewah, rumah tapak

ABSTRACT: The quality factor is considered when people will buy a house. People are willing to pay more for a good quality house, as it will have a high value to resell. Hence, it is imperative to recognize the quality factor in construction. In the present research, the respondents were asked to answer questions regarding houses construction quality in Surabaya and factors affecting it. The results of this research found that eight factors were considered in determining the construction quality of the middle and high-end landed houses in Surabaya. These factors were allocating quality management budget in the project budget, a comprehensive review to the architectural and structural design, supplier management, process management, human resource management, written standardization, customer satisfaction oriented, and proper construction specifications and drawings. From those factors, proper construction specifications and drawings were the most affecting factor to the construction quality.

Keywords: construction quality, middle and high-end house, landed house

\section{PENDAHULUAN}

Penerapan kualitas dalam industri konstruksi telah lebih dulu diterapkan di Jepang sejak tahun 1980-an dan di Amerika sejak tahun 1990-an. Sayangnya, hal ini belum banyak berhasil diterapkan di negara berkembang (Jraisat, Jreisat, \& Hattar, 2016). Turk (2006) menemukan bahwa faktor kualitas terkadang diabaikan dalam bidang konstruksi dengan tujuan memotong 
biaya dan memperpendek durasi proyek. Hambatan yang terjadi dalam penerapan kualitas ke dalam bidang konstruksi adalah penggunaan tenaga kerja yang tidak tetap dan lokasi proyek yang berpindah-pindah (Jraisat et al., 2016). Seiring berkembangnya zaman, minat masyarakat dalam penerapan kualitas telah bertumbuh. Hal ini membuat penerapan kualitas ke dalam suatu produk yang telah lebih dulu dilakukan pada bidang industri manufaktur mulai diadopsi untuk mengatasi permasalahan di bidang konstruksi (Abdel-Salam \& Gad, 2009).

Penerapan kualitas ke dalam suatu produk konstruksi dilakukan karena kualitas menjadi salah satu hal dipertimbangkan masyarakat dalam membeli rumah (Primananda, 2010). Calon pembeli rumah rela membayar lebih untuk mendapatkan sebuah rumah yang berkualitas oleh karena rumah yang berkualitas dihargai cukup tinggi saat akan dijual kembali (Ooi, Le, \& Lee, 2014).

Penerapan Total Quality Management (TQM) merupakan suatu upaya penerapan kualitas ke dalam suatu perusahaan, karena faktor-faktor TQM sudah terbukti memberi peningkatan kinerja perusahaan (Munizu, Ubud Salim, \& Solimum, 2012).

Wanberg, Harper, Hallowell, \& Rajendrans (2013) menemukan faktor lain yang juga berpengaruh terhadap kualitas khususnya dalam dunia konstruksi ialah faktor keamanan dalam bekerja. Mereka menemukan adanya hubungan yang berbanding lurus antara tingkat keamanan dalam bekerja dengan performa kerja yang berkualitas. Selain itu faktor ini dapat menjadi gap yang menarik untuk diteliti lebih lanjut. Jadi penelitian ini bertujuan mengidentifikasi pengaruh faktor-faktor TQM dan faktor keamanan dalam bekerja terhadap kualitas konstruksi rumah menengah dan mewah di Surabaya.

\section{STUDI LITERATUR}

\subsection{Kualitas Konstruksi}

Dalam mewujudkan kualitas, suatu perusahaan membutuhkan perubahan yang radikal terhadap praktek manajemen tradisional (Jraisat \& Sawalha, 2013). Meningkatnya kompetisi dan perubahan persaingan yang terjadi di dunia bisnis, maka banyak perusahaan berusaha mencari tingkat efektivitas yang tinggi dan memilih kualitas sebagai strategi untuk bertahan dalam bisnis.

Di industri konstruksi, kontraktor sangat berperan dalam memenuhi kualitas yang dipersyaratkan dalam biaya dan waktu yang sudah ditentukan (Sweis et al, 2014). Kontraktor, pemilik proyek, dan tim desain memiliki tugas masing-masing yang saling mempengaruhi kinerja keseluruhan proyek untuk menghasilkan produk yang berkualitas.

Menurut Turk (2006), proyek konstruksi yang berkualitas didefinisikan dengan terpenuhinya persyaratan yang diberikan oleh pemilik proyek, tim desain, kontraktor, dan regulasi yang ada. Lalu Jraisat et al. (2016) menyimpulkan bahwa proyek konstruksi yang berkualitas dapat digambarkan dengan terpenuhinya persyaratan dari :

- Pemilik proyek (misalnya kesesuaian fungsi; ketepatan waktu dan kesesuaian anggaran dalam penyelesaian dan siklus pembiayaan operasional dan pemeliharaan),

- Tim desain (misalnya lingkup kerja yang terdefinisi dengan baik; adanya anggaran untuk menggunakan staf yang berkualitas \& berpengalaman; dan mendapatkan informasi lapangan yang jelas sebelum tahap desain; ketepatan waktu dalam pengambilan keputusan oleh pemilik proyek dan tim desain; dan kontrak untuk melakukan pekerjaan yang diperlukan dengan biaya yang wajar),

- Kontraktor (misalnya ketersediaan rencana kontrak, spesifikasi, dan dokumen lainnya yang cukup rinci untuk memungkinkan kontraktor menyiapkan penawaran yang kompetitif; ketepatan dalam pengambilan keputusan oleh pemilik proyek dan tim desain 
untuk perubahan pekerjaan; dan kontrak kerja dengan jadwal yang wajar dengan keuntungan yang masuk akal),

- Badan pengatur publik (misalnya keselamatan dan kesehatan masyarakat sekitar, pertimbangan lingkungan, perlindungan fasilitas umum termasuk utilitas, dan peraturan perundang-undangan yang berlaku).

\subsection{Penerapan TQM dalam Konstruksi}

TQM merupakan suatu sistem manajemen kualitas yang berfokus pada pelanggan dengan melibatkan semua level pada organisasi perusahaan dalam melakukan peningkatan atau perbaikan yang berkesinambungan untuk mencapai keberhasilan jangka panjang (Dhalgaard, Kristensen, \& Kanji, 2007). Ada delapan komponen utama dalam penerapan TQM yaitu kepemimpinan manajemen atas, orientasi peningkatan atau perbaikan, fokus pada pelanggan, keterlibatan di seluruh perusahaan, komitmen terhadap pelatihan dan pendidikan, rasa memiliki dalam proses, penekanan pada pengukuran dan ulasan, dan kerja sama tim.

Melihat kinerja dan produk dari industri manufaktur yang menjadi lebih baik setelah menerapkan TQM, hal ini membuat industri konstruksi mulai menerapkan TQM ke dalam sistem manajemennya. Penelitian-penelitian terdahulu tentang penerapan TQM ke dalam industri konstruksi dapat dilihat pada Tabel 1. Dalam penelitian-penelitian tersebut ditemukan faktor-faktor yang mempengaruhi kualitas konstruksi dan dapat disimpulkan menjadi sembilan faktor.

Tabel 1. Studi Literatur Penerapan TQM dalam Konstruksi

\begin{tabular}{|c|c|}
\hline Faktor & Literatur Pendukung \\
\hline $\begin{array}{l}\text { Komitmen manajemen } \\
\text { atas }\end{array}$ & Pheng \& Teo (2004), Metri (2005), Pheng \& Hong (2005). \\
\hline Kepemimpinan & $\begin{array}{l}\text { Darling (1992), Lam et al. (2008), Haringgton et al. (2012), } \\
\text { Nixon et al. (2012). }\end{array}$ \\
\hline Budaya kerja & Metri (2005), Baird et al. (2011). \\
\hline $\begin{array}{l}\text { Manajemen sumber daya } \\
\text { manusia }\end{array}$ & $\begin{array}{l}\text { Motwani (2001), Metri (2005), Lam et al. (2008), } \\
\text { Altayeb \& Alhasanat (2013). }\end{array}$ \\
\hline $\begin{array}{l}\text { Manajemen yang } \\
\text { strategis }\end{array}$ & Metri (2005), Lam et al. (2008). \\
\hline Manajemen proses & Motwani (2001), Santos et al. (2002), Metri (2005). \\
\hline Manajemen supplier & Pheng \& Teo (2004), Metri (2005), Harrington (2012). \\
\hline $\begin{array}{l}\text { Orientasi terhadap } \\
\text { kepuasan pelanggan }\end{array}$ & Metri (2005), Lam et al. (2008), Harrington et al. (2012). \\
\hline $\begin{array}{l}\text { Manajemen kualitas } \\
\text { desain }\end{array}$ & $\begin{array}{l}\text { Arditi \& Gunaydin (1997), Santos et al. (2002), } \\
\text { Metri (2005), Jraisat et al. (2016). }\end{array}$ \\
\hline
\end{tabular}

\subsection{Keamanan dalam Bekerja dalam Konstruksi}

Kesehatan dan keselamatan kerja (K3) dalam suatu proyek konstruksi merupakan tanggung jawab kontraktor (Shadan \& Fleming, 2012). Kontraktor wajib memiliki perencanaan manajemen keamanan, mengadakan penyuluhan $\mathrm{K} 3$, dan melakukan pengawasan pelaksanaan $\mathrm{K} 3$ terhadap staff dan pekerja yang berada di lokasi proyek.

Wanberg et al. (2013) membuktikan bahwa ada hubungan yang signifikan antara tingkat keamanan dengan kualitas, di mana semakin tinggi tingkat keamanan dalam bekerja, maka kualitas kerja yang dihasilkan juga meningkat. Dari hasil wawancara terbuka dengan manajer proyek ditemukan bahwa 60\% kecelakaan kerja terjadi di pekerjaan ulang (perubahan desain di tengah masa konstruksi \& perbaikan klaim). Penyebabnya ialah pada saat ada pekerjaan 
ulang, kontraktor dituntut adanya penekanan waktu dan kualitas yang sama sehingga menyebabkan kurangnya perhatian terhadap keamanan dalam bekerja.

\section{METODOLOGI PENELITIAN}

\subsection{Alur Penelitian}

Tahapan pertama dalam penelitian ini ialah mencari latar belakang permasalahan yang sedang terjadi dalam dunia konstruksi rumah tapak. Setelah mengetahui permasalahannya, maka dilanjutkan ke tahap studi literatur untuk mengetahui berbagai informasi dan data mengenai kualitas konstruksi serta faktor-faktor yang mempengaruhinya.

Jenis penelitian yang dilakukan ialah penelitian kuantitatif. Maka dari itu, informasi dan data yang sudah terkumpul digunakan sebagai dasar dalam pembuatan kuesioner. Kuesioner dibuat sebagai media untuk pengumpulan data primer. Kuesioner yang telah jadi, dilanjutkan ke tahap penyebaran kuesioner kepada responden yang telah ditetapkan yaitu kontraktor kelas rumah menengah dan mewah di Surabaya.

Terakhir, data yang terkumpul dari kuesioner-kuesioner akan dilanjutkan ke tahap analisis. Teknik analisis data yang digunakan ialah uji validitas dan reliabilitas, analisis deskriptif, korelasi, analisis faktor, dan regresi berganda. Analisis faktor diperlukan untuk mereduksi indikator-indikator yang mewakili faktor-faktor penentu kualitas konstruksi rumah menengah dan mewah di Surabaya. Lalu, faktor-faktor hasil analisis faktor tersebut akan dianalisis menggunakan regresi berganda untuk mengetahui pengaruhnya terhadap kualitas konstruksi rumah menengah dan mewah di Surabaya.

\subsection{Kuesioner}

Kuesioner dalam penelitian ini dibagi menjadi tiga bagian: (1) data responden, (2) kualitas konstruksi rumah menengah dan mewah di Surabaya, (3) faktor-faktor yang mempengaruhi kualitas konstruksi rumah.

Pada bagian pertama "data responden", responden diminta untuk mengisi dari nama, jenis kelamin, usia, jabatan dalam struktur organisasi kontraktor, lama pengalaman di proyek landed house, dan kelas rumah yang sering dibangun. Diharapkan data-data yang terkumpul dapat dianalisis secara deskriptif secara keseluruhan dan berdasarkan jenis kelamin, usia, jabatan, lama pengalaman, dan kelas rumah. Selain itu dapat juga dilakukan analisis regresi berganda terhadap masing-masing kelas rumah sehingga dapat diketahui perbedaan faktor yang mempengaruhi kualitas konstruksi antara rumah menengah dan mewah di Surabaya.

Pada bagian kedua "kualitas konstruksi rumah di Surabaya" terdapat 10 indikator di mana pengisian nilainya menggunakan skala Likert dalam bentuk presentase (skor: 0-100\%, dengan kelipatan 20), sehingga responden dapat mengisi presentase kesesuaian indikator terhadap pengalamannya di dunia konstruksi rumah selama ini.

Pada bagian ketiga "faktor-faktor yang mempengaruhi kualitas konstruksi rumah", dalam bagian ini terdapat tiga puluh indikator yang mewakili kesepuluh faktor penentu kualitas konstruksi rumah. Indikator-indikator tersebut akan dinilai menggunakan skala likert (skor: 16) oleh responden untuk mengetahui seberapa pengaruhnya terhadap kualitas konstruksi rumah.

\section{ANALISIS DAN PEMBAHASAN}

\subsection{Deskripsi Responden}

Responden dalam penelitian ini adalah kontraktor yang membangun rumah kelas menengah dan mewah di Surabaya. Karakteristik responden ini merupakan hasil dari bagian pertama 
kuesioner. Total responden yang diperoleh ialah 98 responden. Mayoritas responden adalah berjenis kelamin laki-laki (89.80\%), berusia antara 20-30 tahun (86.73\%), memiliki jabatan sebagai manajer konstruksi $(71.43 \%)$, dan memiliki pengalaman di proyek landed house kurang dari 10 tahun (91.84\%). Lalu untuk golongan kontraktor terbanyak berasal dari kontraktor rumah kelas menengah $(68.37 \%)$.

\subsection{Uji Validitas dan Reliabilitas}

Uji validitas dan reliabilitas dilakukan terhadap sepuluh indikator kualitas konstruksi rumah di Surabaya dan tiga puluh indikator faktor-faktor yang mempengaruhi kualitas konstruksi rumah.

Dalam uji validitas terhadap sepuluh indikator kualitas kontruksi rumah di Surabaya, hasilnya memenuhi persyaratan uji validitas. Sedangkan pada uji validitas terhadap tiga puluh indikator faktor-faktor yang mempengaruhi kualitas konstruksi rumah, hasilnya menunjukkan ada satu indikator yang tidak memenuhi persyaratan. Indikator tersebut ialah "tidak menerapkan kontrak kerja borongan". Maka indikator tersebut dihilangkan, lalu dilanjutkan pengujian reliabilitas.

Dalam uji reliabilitas terhadap sepuluh indikator kualitas konstruksi rumah di Surabaya dan 29 indikator faktor-faktor yang mempengaruhi kualitas konstruksi rumah, hasilnya menunjukkan memenuhi persyaratan uji reliabilitas dan seluruh indikator memiliki nilai cronbach's alpha > 0.7 (memiliki reliabilitas tinggi).

\subsection{Analisis Deskriptif}

Analisis deskriptif dalam penelitian ini mengacu pada nilai rata-rata (mean) masing-masing indikator. Gambaran responden tentang kualitas konstruksi rumah di Surabaya, responden setuju jika rumah yang berkualitas memiliki kesesuaian fungsi rumah terhadap ketentuan dari pemilik proyek. Responden tidak setuju jika rumah yang berkualitas dihasilkan karena ada staf yang berkualitas dan berpengalaman.

Sesudah itu, gambaran responden tentang faktor-faktor yang mempengaruhi kualitas konstruksi rumah, responden setuju jika spesifikasi konstruksi dan gambar yang jelas mempengaruhi kualitas konstruksi rumah. Responden tidak setuju jika perencanaan manajemen keamanan dan penyuluhan K3 mempengaruhi kualitas konstruksi rumah.

\subsection{Uji Korelasi}

Uji korelasi dilakukan untuk mengetahui adanya hubungan antara kualitas konstruksi rumah di Surabaya dan faktor-faktor yang mempengaruhi kualitas konstruksi rumah dalam penelitian ini. Untuk mengetahui korelasi antara kedua variabel tersebut, dilakukan uji korelasi Pearson. Hasil menunjukkan nilai Sig. adalah $0.004(<0.1)$, yang artinya ada korelasi atau hubungan antara kualitas konstruksi rumah di Surabaya dengan faktor-faktor yang mempengaruhi kualitas konstruksi rumah.

\subsection{Analisis Faktor}

Analisis faktor digunakan untuk mereduksi 29 indikator faktor-faktor yang mempengaruhi kualitas konstruksi rumah. Pada tahap awal analisis faktor, pengujian KMO and Bartlett's test dan anti-image matrices menunjukkan 29 indikator telah memenuhi persyaratan untuk dilanjutkan ke tahap berikutnya. Pada tahap menentukan berapa faktor yang mungkin terbentuk, dari tabel total variance explained menunjukkan ada delapan faktor yang terbentuk. Tabel 2 menunjukkan delapan faktor yang terbentuk dari analisis faktor. 
Tabel 2. Delapan Faktor yang Terbentuk Hasil Analisis Faktor

\begin{tabular}{cl}
\hline No. & \multicolumn{1}{c}{ Faktor } \\
\hline 1 & Pengalokasian dana untuk manajemen kualitas dalam budget proyek \\
2 & Peninjauan secara menyeluruh terhadap desain arsitektur dan struktur \\
3 & Manajemen supllier \\
4 & Manajemen proses \\
5 & Manajemen sumber daya manusia \\
6 & Standarisasi tertulis \\
7 & Orientasi terhadap kepuasan pelanggan \\
8 & Spesifikasi konstruksi dan gambar yang jelas \\
\hline
\end{tabular}

\subsection{Regresi Berganda}

Analisis regresi berganda dilakukan untuk mengetahui pengaruh delapan faktor hasil analisis faktor terhadap kualitas konstruksi rumah menengah dan mewah di Surabaya. Analisis dilakukan terhadap 3 kelompok, yaitu kelompok rumah menengah, rumah mewah, dan seluruh kelompok kelas rumah. Persamaan yang diperoleh dari hasil analisis regresi berganda ini ialah :

Kualitas konstruksi rumah menengah di Surabaya $=19.354+3.200 \times 5+\varepsilon$

Kualitas konstruksi rumah mewah di Surabaya $=0$

Kualitas konstruksi rumah di Surabaya $=19.701+2.860 \times 8+\varepsilon$

Persamaan 1 menunjukkan bahwa faktor yang mempengaruhi kualitas konstruksi rumah menengah di Surabaya ialah faktor manajemen sumber daya manusia (X5). Sedangkan Persamaan 2 menunjukkan bahwa tidak ada faktor yang mempengaruhi kualitas konstruksi rumah mewah di Surabaya. Terakhir, persamaan 3 menunjukkan bahwa faktor yang mempengaruhi kualitas konstruksi rumah menengah dan mewah di Surabaya ialah faktor spesifikasi konstruksi dan gambar yang jelas (X8).

\section{KESIMPULAN, SARAN DAN PENGEMBANGAN PENELITIAN}

Delapan faktor yang dipertimbangkan terhadap penentuan kualitas konstruksi rumah menengah dan mewah di Surabaya ialah :

1. Pengalokasian dana untuk manajemen kualitas dalam budget proyek,

2. Peninjauan secara menyeluruh terhadap desain arsitektur dan struktur,

3. Manajemen supplier,

4. Manajemen proses,

5. Manajemen sumber daya manusia,

6. Standarisasi tertulis dalam kontrak,

7. Orientasi terhadap kepuasan pelanggan,

8. Spesifikasi konstruksi dan gambar yang jelas.

Faktor yang sangat mempengaruhi kualitas konstruksi rumah menengah dan mewah di Surabaya ialah spesifikasi konstruksi dan gambar yang jelas.

Jika dilakukan analisis regresi berganda pada masing-masing kelas rumah, maka hasilnya :

1. Pada rumah kelas menengah ditemukan faktor yang sangat berpengaruh terhadap kualitas konstruksinya ialah manajemen sumber daya manusia.

2. Sedangkan pada rumah kelas mewah tidak ditemukan faktor yang berpengaruh terhadap kualitas konstruksinya.

Saran bagi pengembang dan konsultan arsitektur rumah kelas menengah dan mewah di Surabaya yaitu lebih meningkatkan kepedulian dan perhatian terhadap kejelasan spesifikasi 
konstruksi dan gambar sejak tahap perencanaan. Ini dapat membantu kontraktor yang berperan langsung dalam mewujudkan kualitas konstruksi di suatu proyek.

Saran untuk pengembangan penelitian ini adalah :

1. Mengingat keterbatasan responden antara kontraktor rumah menengah dan mewah yang menyebabkan tidak diperolehnya hasil yang signifikan pada faktor yang mempengaruhi kualitas konstruksi rumah mewah di Surabaya. Disarankan berikutnya dapat dilakukan penelitian yang sama dengan jumlah responden yang lebih banyak dan jumlahnya berimbang.

2. Selain penerapan faktor-faktor TQM, dalam studi literatur penelitian ini ditemukan penerapan metode lain untuk mencapai kualitas suatu produk yaitu lean six sigma. Maka berikutnya dapat dilakukan penelitian tentang penerapan lean six sigma ke dalam industri konstruksi dan juga dapat dicari perbedaannya terhadap penerapan TQM dalam industri konstruksi.

\section{DAFTAR REFERENSI}

Abdel-Salam, Hisham M.E. \& Gad, Medhat M. (2009). Cost of Quality In Dubai: An Analytical Case Study Of Residential Construction Projects. International Journal of Project Management, 27, 501-511.

Altayeb, Mustafa Maher \& Alhasanat, Mahmoud Bashir. (2014). Implementing Total Quality Management (TQM) in the Palestinian Construction Industry. International Journal of Quality \& Reliability Management, 31(8), 878-887.

Arditi, David \& Gunaydin, H. Murat. (1997). Total Quality Management in the Construction Process. International Journal of Project Management, 15(4), 235-243.

Baird, Kevin, Jia Hu, Kristal, \& Reeve, Robert. (2011). The Relationships between Organizational Culture, Total Quality Management Practices and Operational Performance. International Journal of Operations \& Production Management, 31(7), 789814.

Darling, John R. (1992). Total Quality Management: The Key Role of Leadership Strategies. Leadership \& Organization Development Journal, 13(4), 3-7.

Dhalgaard, Jens J., Kristensen, Kai, \& Kanji, Gopal K. (2007). Fundamentals of Total Quality Management. London : Taylor \& Francis e-Library.

Harrington, H. James, Voehl, Frank \& Wiggin, Hal. (2012). Applying TQM to the Construction Industry. The TQM Journal, 24(4), 352-362.

Jraisat, Luai E. \& Sawalha, Ihab H. (2013). Quality Control and Supply Chain Management: A Contextual Perspective and a Case Study. Supply Chain Management : An International Journal, 18(2), 194-207.

Jraisat, Luai, Jreisat, Lana \& Hattar, Christine. (2016). Quality in Construction Management: an Exploratory Study. International Journal of Quality \& Reliability Management, 33(7), 920-941.

Lam, K.C., Wang, D., and Lam, M.C.K. (2008). The TQM Journey of Hong Kong Building Contractors: from a Self-Assessment Perspective. TQM Magazine, 20(6), 556-569.

Metri, Bhimaraya A. (2005). TQM Critical Success Factors for Construction Firm. Management Magazine, 10(2), 61-77.

Motwani, Jaideep. (2001). Critical Factors and Performance Measures of TQM. The TQM Magazine, 13(4), 292-300.

Munizu, Musran, Ubud Salim, Surachman, \& Solimum. (2012). Pengaruh Praktik Total Quality Management (TQM) terhadap Budaya Kualitas, Daya Saing, dan Kinerja Perusahaan (Studi pada Industri Manufaktur di Kota Makassar). Jurnal Aplikasi Manajemen, 10(3). 
Nixon, Phil, Harrington, Megan, \& Parker, David. (2012). Leadership Performance is Significant to Project Success or Failure: A Critical Analysis. International Journal of Productivity and Performance Management, 61(2), 204-216.

Ooi, Joseph T.L., Le, Thao T.T., \& Lee, Nai-Jia. (2014). The Impact of Construction Quality on House Prices. Journal of Housing Economics, 26, 126-138.

Pheng, Low Sui \& Teo, Jasmine Ann. (2004). Implementing Total Quality Management in Construction Firms. Journal of Management in Engineering, 20, 8-15.

Pheng, Low Sui \& Hong, Sze Hui. (2005). Strategic Quality Management for The Construction Industry. TQM Magazine, 17(1), 35-53.

Primananda, Agustinus. (2010). Faktor-Faktor yang Mempengaruhi Konsumen dalam Membeli Rumah. Semarang, Universitas Diponegoro.

Santos, Aguinaldo, Formoso, Carlos Torres and Tookey, J.E. (2002). Expanding the Meaning of Standardization Within Construction Process. The TQM Magazine, 14(1), 25-33.

Shadan, Kam P.E. \& Fleming, Gannet, Inc. (2012). Construction Project Management Handbook. FTA Report No. 0015, Federal Transit Administration.

Sweis, Rateb J., Shanak, Rifat O., El Samen, Amjad Abu, \& Suifan, Taghrid. (2014). Factors Affecting Quality in the Jordanian Housing Sector. International Journal of Housing Markets and Analysis, 7(2), 175-188.

Turk, A.M. (2006). ISO 9000 in Construction: An Examination of its Application in Turkey. Turkey : Building and Environment, 41, 501-511.

Wanberg, J., Harper, C., Hallowell, M. R., and Rajendran, S. (2013). Relationship Between Construction Safety and Quality Performance. Journal Construction Engineering Management, 139(9), 401-411. 